\title{
THE USE OF ANCILLARY LABORATORY TESTS IN LEPTOSPIROSIS, WITH PARTICULAR REFERENCE TO THE DIAGNOSIS OF THE MILD CASE

\author{
BY
}

\author{
C. R. ROBINSON* \\ From a British Military Hospital in Malaya
}

(RECEIVED FOR PUBLICATION JANUARY 1, 1957)

The incidence of leptospirosis in British troops serving in Malaya has afforded a good opportunity for the comparative evaluation of the clinical and laboratory examinations of a large number of mild cases of the disease, and the use of these tests in diagnosis and in the differentiation of leptospirosis from other causes of fever (Robinson and Kennedy, 1956 ; McCrumb, Stockland, Robinson, Turner, Levis, Maisey, Kelleher, Gleiser, and Smadel, 1957). It is hoped that the results obtained from the present series of cases will, by supplementing an all too scanty literature, contribute to further understanding of the reaction to infection in the mild case of leptospirosis.

\section{Materials and Methods}

Selection of Cases.-Tests were performed on 89 Service men. Of these, 78 were British and 11 Gurkha. The mean age was 21 years.

Definitive Diagnosis. - All showed a diagnostic rise of leptospiral antibodies as tested by the agglutinationlysis technique. Of the leptospira isolated, 29 were identified as members of seven sero groups (Table I).

TABLE I

SERO GROUP DISTRIBUTION OF 29 IDENTIFIED STRAINS OF LEPTOSPIRA

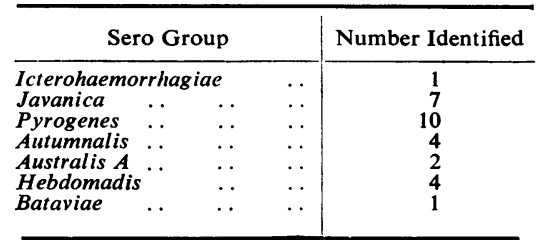

Laboratory Investigations.-These are summarized in Table II.

\section{Results}

Haematological Investigations.-Table III gives an overall picture.

\footnotetext{
*Prisent address: School of Hygiene, University of Toronto Canada.
}

TABLE II

NUMBER OF CASES, TESTS, AND METHODS

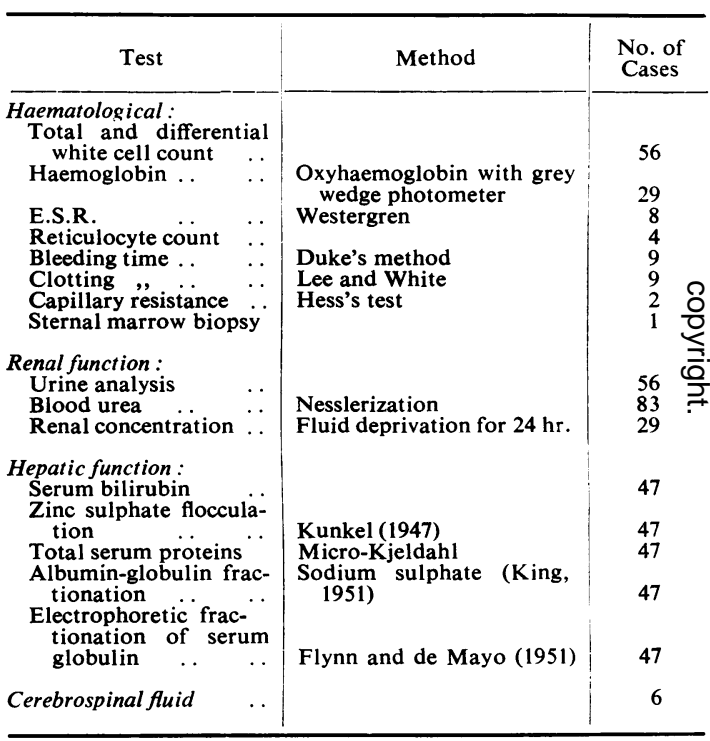

TABLE III

INCIDENCE OF HAEMATOLOGICAL FINDINGS

\begin{tabular}{|c|c|c|}
\hline \multirow{2}{*}{$\begin{array}{l}\text { Estimation } \\
\text { (Results as Percentages of Com- } \\
\text { bined Totals Representing One-week } \\
\text { Periods) }\end{array}$} & \multicolumn{2}{|c|}{$\begin{array}{c}\text { Percentage of Cases Showing } \\
\text { Abnormality }\end{array}$} \\
\hline & First Week & Second Week \\
\hline $\begin{array}{l}\text { Leucocytosis (above } 10,000 / \mathrm{cmm} .) \\
\text { Leucopenia (below } 4,000 / \mathrm{c} . \mathrm{mm} .)\end{array}$ & $\begin{array}{l}37 \\
3 \cdot 7\end{array}$ & $22 \cdot 9$ \\
\hline $\begin{array}{l}\text { Absolute neutrophil increase (above } \\
7,500 \text { 'c.mm.) }\end{array}$ & $33 \cdot 3$ & $10 \cdot 5$ \\
\hline $\begin{array}{l}\text { Absolute neutropenia (below } 2,500 / \\
\text { c.mm.) }\end{array}$ & 9.8 & $13 \cdot 1$ \\
\hline $\begin{array}{l}\text { Absolute lymphocyte increase (above } \\
3,500 \text {; c.mm.) }\end{array}$ & 0 & $5 \cdot 2$ \\
\hline $\begin{array}{l}\text { Absolute monocyte increase (above } \\
800 / \mathrm{c} . \mathrm{mm} .)\end{array}$ & 0 & 28.9 \\
\hline
\end{tabular}

Total and Differential White Cell Counts.-Of the 56 cases tested, $23(46 \%)$ showed leucocytosis during the course of the illness. The highest 


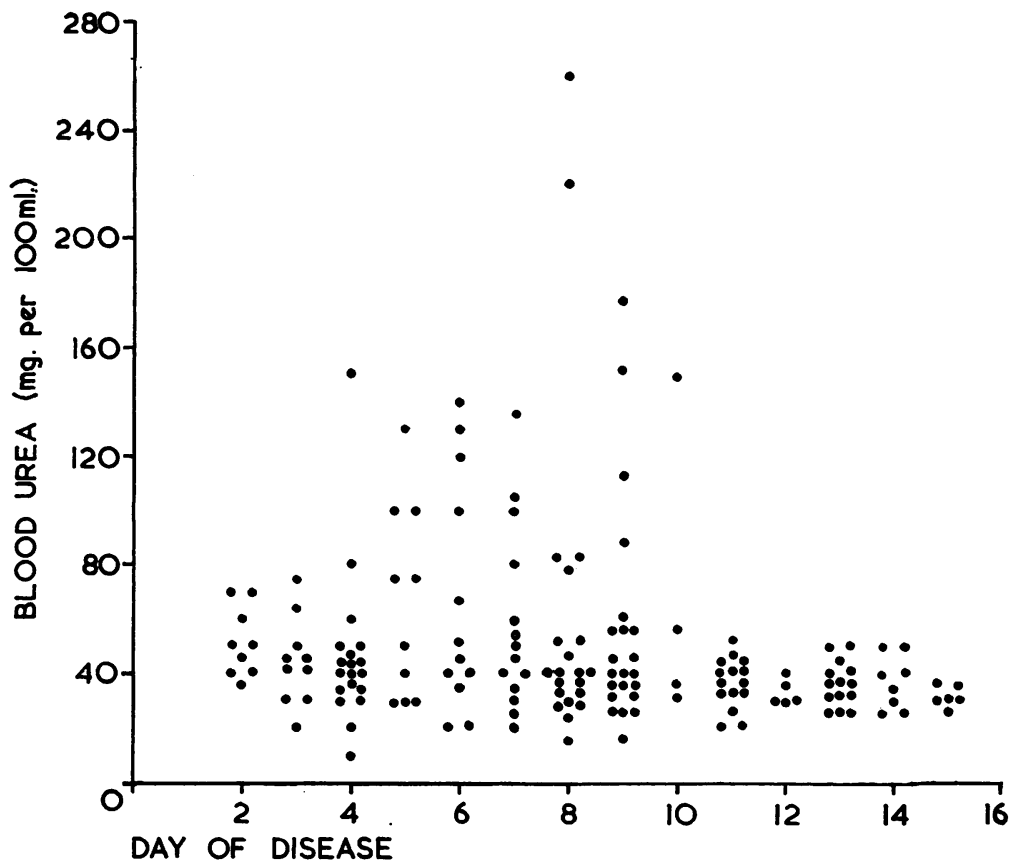

Fig. 1.-The blood urea level in relation to day of disease (normal upper limit $=\mathbf{4 0} \mathrm{mg}$. per $100 \mathrm{ml}$.).

The mean corpuscular haemoglobin concentration, which was estimated in 12 cases of anaemia, was slightly lowered in all. The total red cell count was also slightly lowered; the film appearances were, however, normal. Repeated counts failed to demonstrate a reticulocyte response, even in those cases with marked urobilinogenuria. The red cell fragility in the two cases which showed the greatest fall in the haemoglobin level was normal.

Bleeding $\mathrm{t}$ i m es, clotting t i m e s, capillary resistance tests, and repeated platelet

observed was $20,000 /$ c.mm., but in the majority of cases the counts lay between 10,000 and $16,000 /$ c.mm. A leucocytosis of $12,000 /$ c.mm. was seen in one case as late as the 21st day of illness. An absolute monocyte increase was observed in 10 cases during the second week, which in one case was $4,000 /$ c.mm. but in the remainder was between 900 and $1,000 /$ c.mm. There was no notable variation in the lymphocyte or eosinophil counts.

Haemoglobin.-For the purpose of the investigation $13 \mathrm{~g}$. \% was taken as the lower normal limit. Using this criterion, 18 of the 29 British Service men tested showed anaemia. The lowering was greatest during the first week when, in one instance, a value of 7.8 g. \% was obtained on the sixth day of illness. However, in most of the cases the haemoglobin level did not fall below $10 \mathrm{~g}$.\%. Four of eight cases tested showed anaemia beyond the second week of illness.

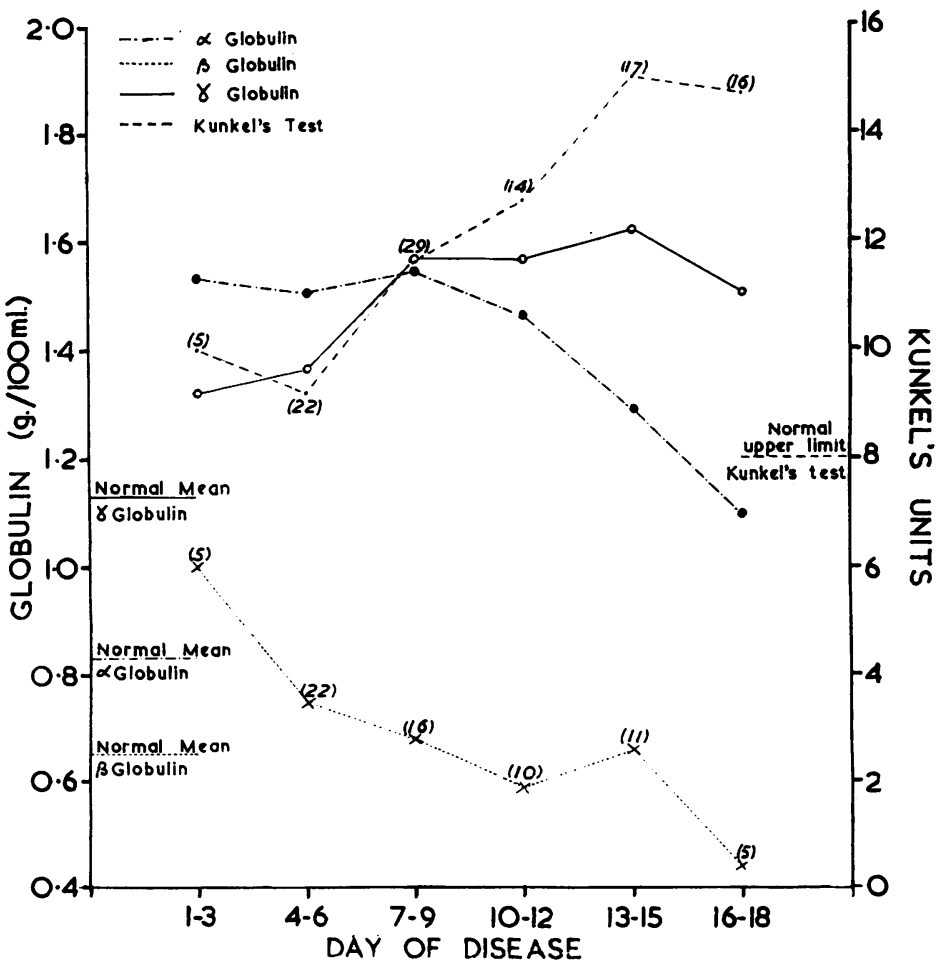

Fig. 2.-Showing the pattern of the serum globulin fractions as compared with the Kunkel's test. Results represented as means of combined totals (brackets) over three-day periods. 
counts which were performed on those patients who showed haemorrhagic manifestations were also normal in every case.

Sternal marrow biopsy was performed in one case where the haemoglobin had fallen to $10 \mathrm{~g} . \%$ on the fourteenth day of illness and showed a normal appearance and distribution of cells.

Erythrocyte Sedimentation Rate (Westergren). -This was raised in all cases, though normal values were obtained during the first week of illness in two cases. The sedimentation rate was in most cases not greatly raised, a very mild case reaching a maximum of $11 \mathrm{~mm}$. in the first hour, and a moderately severe case showing an increase to $112 \mathrm{~mm}$. In another case of equal severity, however, the sedimentation rate did not exceed $25 \mathrm{~mm}$. in the first hour.

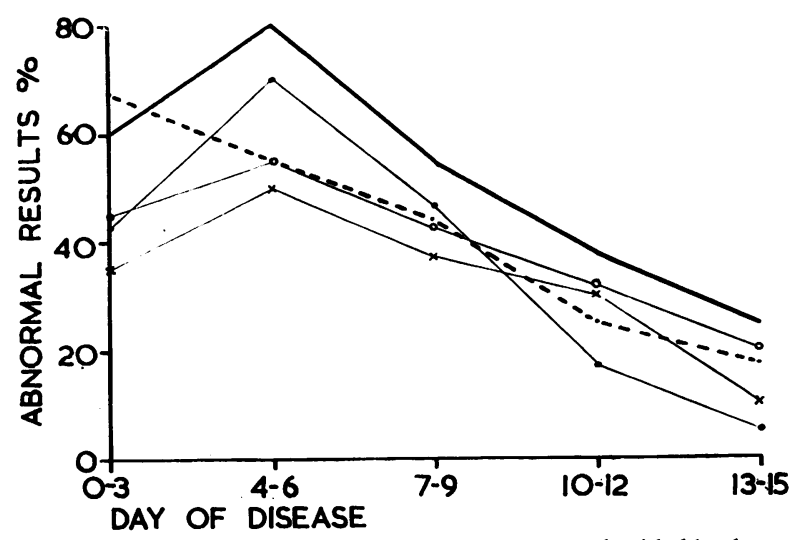

FIG. 3.-Examination of urinary sediment as compared with blood urea estimation. Results represented as combined totals over three-day periods. - urine abnormality. $----\frac{-}{x}$ blood urea.

proteinuria. $0-0$ pyuria. $X-X$ cylindruria.

Renal Function.-Fifty-six cases were tested. Of these, 48 showed abnormality of the urinary deposit, either pyuria, cylindruria, or haematuria (Fig. 3).

Urine Analysis.-The mean duration of urinary abnormality was 10 days (Table IV). Changes

TABLE IV

INCIDENCE OF URINARY ABNORMALITY COMPARED WITH ELEVATION OF BLOOD UREA LEVEL

\begin{tabular}{|c|c|c|c|}
\hline \multirow{2}{*}{ 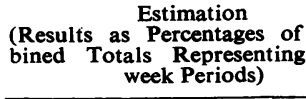 } & \multirow{2}{*}{$\begin{array}{c}\text { Com- } \\
\text { One- }\end{array}$} & \multicolumn{2}{|c|}{$\begin{array}{c}\text { Percentage of Cases Showing } \\
\text { Abnormality }\end{array}$} \\
\hline & & First Week & Second Week \\
\hline 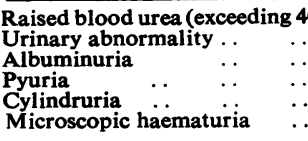 & $\begin{array}{c}0 \mathrm{mg} . \% \\
\ldots \\
\ldots \\
\ldots \\
\ldots\end{array}$ & $\begin{array}{l}74 \cdot 5 \\
87 \cdot 5 \\
84 \cdot 0 \\
64 \cdot 3 \\
73 \cdot 2 \\
32\end{array}$ & $\begin{array}{r}43 \cdot 3 \\
52 \cdot 8 \\
32 \cdot 0 \\
37 \cdot 5 \\
40 \cdot 6 \\
8 \cdot 0\end{array}$ \\
\hline
\end{tabular}

were seen as early as the second day of illness, although in five cases they were not present until the second week. The changes found were in most cases slight. In an average case, the spun deposit would reveal $10-20$ pus cells per highpower field with hyaline, granular, or pus casts. In many cases the pyuria amounted to little more than a slight excess of pus cells, and additional significance was usually given to this finding by the presence of cylindruria. The presence of hyaline casts was an early finding; later, granular and pus casts made their appearance. The presence of occasional hyaline casts was, however, found as a late sign which was often present in the third week of illness in the absence of other signs of urine abnormality.

Marked urobilinogenuria (as judged by a positive Ehrlich reaction in a dilution of urine exceeding 1 in 32) was present in 11 cases, in one instance on the first day of illness, but in the other cases the tests were not made earlier than the fourth day. Two of these cases were icteric and nine were not. Biliuria and cholaluria were only seen when the serum bilirubin was raised.

Blood Urea.-As can be seen from Table IV and Fig. 1 the elevation of the bloof urea was in most cases moderate. The highest values were obtained between the fourth and tenth days of illness.

Water Concentration Tests.-The results of single test observations performed at times varying from the ninth to the 65th day of illness suggest that renal concentration is not markedly impaired.

Tests of Hepatic Function.-The serum $\frac{\hat{O}}{0}$ bilirubin level was raised in 12 cases. The highest figures were seen between the third and seventh days of illness and ranged between 1 and $ᄋ$ $2 \mathrm{mg}$. per $100 \mathrm{ml}$., but in three instances the level $₹$ exceeded $3 \mathrm{mg}$. per $100 \mathrm{ml}$. Twenty-nine per cent. 윽 of cases subjected to Kunkel's test (Fig. 2) showed $\supset$ raised values during the first week, and $63 \%$ during the second week of illness. The highest figures $\bar{N}$ were obtained from the ninth to 17th day of ? illness.

Total Serum Proteins.-There was no lowering of the total proteins below the normal mean. Analysis of the serum proteins showed reduced serum albumin during the first 14 days of illness. $\mathbb{D}$ There was a concomitant rise of serum globulin, ? due mostly in the early phase of the illness to an $\frac{T}{0}$ increase of alpha globulin, and in the later stages $\frac{\vec{D}}{\mathbb{D}}$

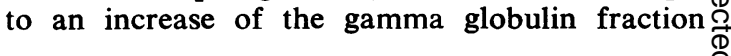


(Fig. 2). These changes occurred earlier and were more marked in the icteric than the anicteric cases.

Cerebrospinal Fluid.-Examination was performed in six cases, on the second, third, fourth, and fifth days of illness. One case showed on the fourth day a slight increase in cells and protein. In the other cases the fluid was normal.

\section{Discussion}

Most of the available information on the use of ancillary laboratory investigations in the diagnosis of leptospirosis has been derived from the study of severe cases. In the milder case, however, the changes are less marked and prone to greater variation and their interpretation is in consequence a matter of greater difficulty. It is therefore of advantage to be aware of the pattern of changes which occur during the course of the disease, and of the time when the laboratory tests are most likely to be of value.

Evidence of renal involvement is by far the most constant and distinctive feature of the mild case. Elevation of the blood urea is a diagnostic and prognostic sign of great value, which may occur independently of other evidence of renal or hepatic damage (Austoni, 1953). Moderate elevation is the rule, and the test is of greatest use during the early phase of the illness, when raised values are found in the absence of urinary abnormality. Later in the course of the disease there is a closer correlation between the blood urea level and demonstrable urinary findings (see Fig. 3). The slight increases of the blood urea level are of doubtful significance, as these may be present in early stages of other fevers. In such cases a raised blood urea level is more significant if there is abnormality in the urinary deposit. These include pyuria, cylindruria, and in some cases haematuria, which may be very slight but are of great significance in the diagnosis of the disease and in its differentiation from other causes of fever in the tropics.

In the present investigation elevation of the serum bilirubin and biliuria were of great diagnostic value, but abnormal results obtained by the flocculation tests and analysis of the serum proteins, although similar to those found by Ceresa (1954), Vignato and Austoni (1950), Austoni (1953) and others, were not of value in differentiating the disease from proved cases of scrub typhus, dengue, and other non-leptospiral fevers.

The leucocyte response in these mild cases is not striking, but polymorphonuclear leucocytosis when it occurs affords good supporting evidence. On the other hand, the presence of leucopenia does not rule out the diagnosis of leptospirosis and has been found by Broom (1951), Daniels and Grennan (1943), and also in the present series.

Anaemia may be present even in the mildest cases of leptospirosis. Usually it is hypochromic and probably due to dyshaemopoiesis. Haemolysis plays a small and insignificant part, and a substantial anaemia may occur, as in several of the present cases, in the absence of hyperbilirubinaemia or an increased excretion of urobilinogen.

The erythrocyte sedimentation rate is thought usually to increase early in the illness, but not invariably, and a normal E.S.R. by no means excludes the diagnosis of leptospirosis. Its value in the differentiation of leptospiral from viral meningitis is discussed by Scheid (1949).

Abnormality of the cerebrospinal fluid is frequently found, and may occur in the absence of clinical evidence of meningism. Likewise the changes found bear no relation to the gravity of symptoms, and the C.S.F. may be normal despite the presence of marked meningeal signs. The pattern of cytological changes shows great variation. Differential counts as a rule show a lymphocytic picture, with the proportion of lymphocytes usually exceeding $70 \%$, the remainder of the cells being polymorphs. In a third of cases polymorphs predominate and may be as high as $90 \%$ of the total cell count. After the eleventh day the percentage of polymorphs does not often exceed $30 \%$. The protein content is increased in proportion to the degree of cellular response. The glucose and chloride levels show no lowering, which may be of value in distinguishing this disease from the early stages of tuberculous meningitis (Broom, 1951).

There remains in conclusion the need to compare the findings in this group of young and otherwise physically fit soldiers with those obtained under the more varied conditions of civilian life in Great Britain. Whereas mild urinary changes were of great value for diagnosis in Malaya, in older people cylindruria and slight proteinuria do not have the same import. This also applies to a slight increase in blood urea. In Malaya the cases were seen at a very early stage of the illness, sometimes on the day of onset. It is likely that in this country many cases of canicola fever are overlooked because of their mildness or are diagnosed at a later stage.

\section{Summary}

The results of the use of a variety of ancillary laboratory tests performed on 89 cases of mild leptospirosis are presented. 
The use of these tests in the early diagnosis of leptospirosis is evaluated.

The value of urine analysis is stressed, and also the lack of specific diagnostic value of liver function tests in this disease.

The serum protein estimations and electrophoretic fractionation of the serum globulins were performed by Dr. R. Young, the Institute for Medical Research, Kuala Lumpur. I wish to thank him for the unfailing help which he gave me, and for the use of his results.

I wish to thank the United States Army Medical Research Unit, Malaya, and also Dr. J. C. Broom, the Wellcome Laboratories of Tropical Medicine, London, without whose aid this study would not have been possible.

The D.G.A.M.S. has given permission to publish.

$$
\text { REFERENCES }
$$

Austoni, M. (1953). Le Leptospirosi. Padua.

Broom, J. C. (1951). Monthly Bull. Minist. Hlth (Lond.), 10, 258.

Ceresa, C. (1954). Minerva med. (Torino), 45 (1), 1817.

Daniels, W. B., and Grennan, H. A. (1943). J. Amer. med. Ass., 122, 361 .

Flynn, F. V., and Mayo, P. de (1951). Lancet, 2, 235

King, E. J. (1951). Micro-analysis in Medical Biochemistry, 2nd ed., p. E1. J. (1951). Micro-analy
. Churchill, London.

Kunkel, H. G. (1947). Proc. Soc. exp. Biol. (N.Y.), 66, 217.

McCrumb, F. R., Jr, Stockland, J. L., Robinson, C. R., Turner, L. H. Levis, D. G., Maisey, C. W., Kelleher, M. F., Gleiser, C. A., and Smadel, J. E. (1957). Amer. J. trop. Med., 6, 238.

Robinson, C. R., and Kennedy, H. F. (1956). J. roy. Army med. Cps, 102, 196.

Scheid, W. (1949). Dtsch. med. Wschr., 74, 898.

Vignato, L., and Austoni, M. (1950). Clin. nuova, 10, 1. 